\title{
Glacier-climate interaction at low latitudes
}

\author{
GEORg KASER \\ Institut für Geographie, Universität Innsbruck, Innrain 52, A-6020 Innsbruck, Austria
}

\begin{abstract}
In the low latitudes there is an absence of major thermal seasonality, yet there are three different climate regimes related to global circulation patterns and their seasonal oscillation: the humid inner tropics, the dry subtropics and, intermediate between these two, the outer tropics. For the respective glacier regimes the vertical profiles of specific mass balance (VBPs) are modeled considering vertical gradients of accumulation, air temperature and albedo, the duration of the ablation period and a factor for the ratio between melting and sublimation. The model is first calibrated with data from Hintereisferner, Austrian Alps, and is then applied to tropical conditions. The simulated VBP matches well the measured profiles from Irian Jaya and Mount Kenya. Due to lack of field evidence, the subtropical VBP cannot be verified directly. However, application of the respective model versions separately to the humid and dry seasons of the outer-tropical Glaciar Uruashraju, Cordillera Blanca, Peru, provides reasonable results. Glaciers in the humid inner tropics are considered to be most sensitive to variations in air temperature, while dry subtropical glaciers are most sensitive to changes in air humidity. The two seasons of the outer tropics have to be viewed from these different perspectives.
\end{abstract}

\section{INTRODUGTION}

Motivated primarily by investigations of global change, the scientific community has become increasingly aware that low-latitude mountain environments are highly sensitive indicators of climate change (e.g. Thompson and others, 1995; Broecker, 1997). Glaciers, especially, have become the subject of intensive observation. Corresponding to global trends, they have retreated significantly since the mid-19th century (e.g. Hastenrath, 1995; Kaser, 1999). Several analyses show that it is not only increased temperature and/or decreased precipitation that are responsible for these retreats, but also changes in air humidity (Kaser and Noggler, 1991; Hastenrath and Kruss, 1992; Kaser and others, 1996b; Kaser and Georges, 1997; Kaser 1999; Wagnon and others, 1999).

A few attempts have been made to derive climate scenarios from reconstructed paleo-glaciations in low latitudes (e.g. Klein and others, 1999; Hostetler and Clark, 2000), but they do not deal adequately with the particular circumstances of different low-latitude glacier regimes. In this paper I outline these regimes and propose a model which simulates the basic characteristics of low-latitude glacier-climate interaction. Different climate regimes and their respective glacier regimes are distinguished and defined. Then the model and the derived vertical profiles of specific mass balance (VBPs) for each regime are presented, and the model results are compared with the few available measured VBPs. Finally, the sensitivity of the equilibrium-line altitude (ELA) of low-latitude glaciers to changes in various climate variables is discussed. Preliminary elements of this concept, concerning the tropics, were published earlier (Kaser, 1995; Kaser and others, 1996a). The concept is herein extended to the subtropics.

\section{GLIMATE AND GLACIER REGIMES AT LOW LATITUDES}

The following is a generalized and simplified depiction of climate regimes at low latitudes. Although there are various deviations from this idealized scheme in reality, the simplifications are justified by the attempt to address the basic differences between the regimes.

Two principal features of global zonal circulation characterize low latitudes, the Inter-Tropical Convergence (ITC) and the trade winds. Whereas the ITC is part of a humid climate, trade winds are connected with particularly dry conditions. The respective climate zones are known as the tropics and the subtropics. The annual cycle of solar radiation leads to an oscillation in the dynamic circulation pattern, which is smaller above water surfaces and greater on continents. Hence, only the inner tropics have continuously humid conditions. At the outer limits of the tropics, there is only one rainy season per year. Thus, the outer tropics can be treated as an intermediate zone between the tropics and the subtropics; during the humid season they have tropical conditions, and during the dry season, subtropical conditions.

From the glaciological perspective of this paper, the following requirements must be met for an area to be considered to lie in the tropics (inner and outer): it must be within: (i) the astronomical tropics (radiative delimitation); (ii) the area where the daily temperature variation, $\Delta T_{\mathrm{d}}$ exceeds the annual temperature variation, $\Delta T_{\mathrm{y}}$ (thermal delimitation); and (iii) the oscillation area of the ITC zone (ITCZ) (hygric delimitation) (Kaser, 1995; Kaser and others, 1996a). The resulting delimitations for tropical glaciers and the distribution of glacier area by country are shown in Figure 1. The ITC and the frontal activities of the westerlies reach the subtropics only sporadically. Thus the subtropics are quite dry. The seasonality of low latitudes can only be delimited by hygric considerations as there is an absence of major thermal seasonality. As a model assumption, this applies to the area where daily variations of air temperature exceed annual variations. This area, especially over South America, reaches rather far into the subtropics (Fig. 1). Hence, three glacier regimes can be derived: 


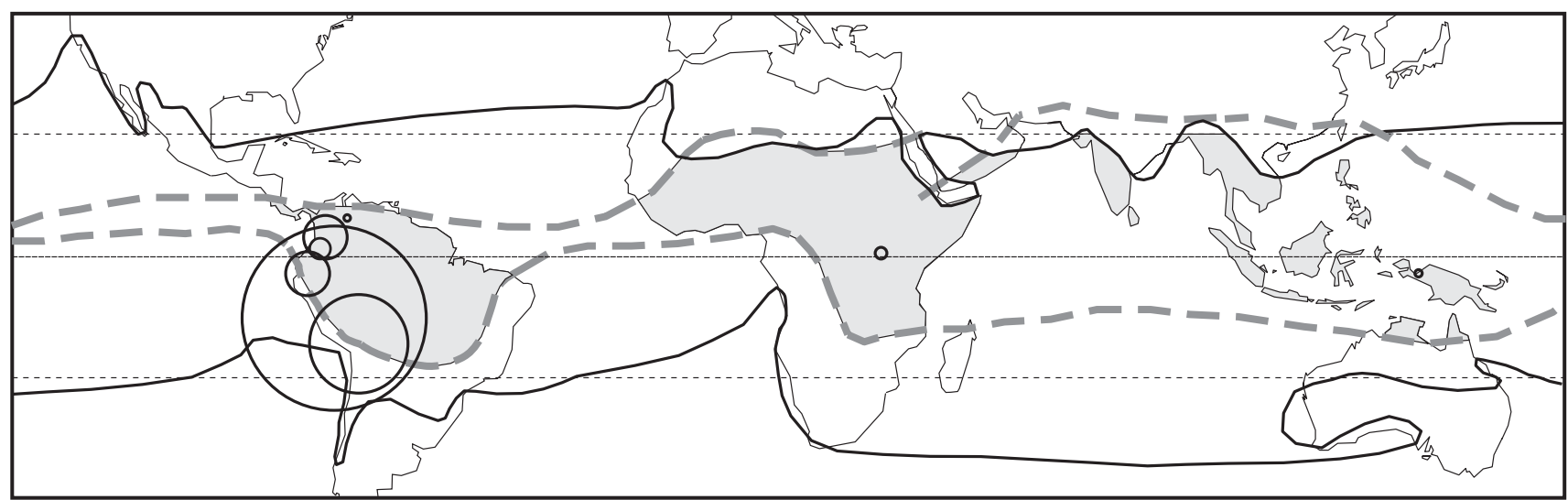

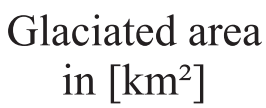

Glaciated area in $\left[\mathrm{km}^{2}\right]$

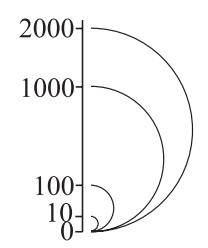

Tropics of Cancer and Capricorn

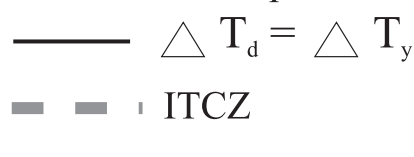

Continental area within each of the three delimitations

Fig. 1. The tropics and their delimitations from a glaciological point of view, and the distribution of glacier areas by country (after Kaser and others, 1996a). The circles are centered on the respective country with the exception that all East African glaciers are represented by a single circle. The bold dashed lines show the boundaries of the seasonal oscillation of the ITCZ.

In the humid inner tropics, stable humidity and temperature conditions cause accumulation and ablation to occur simultaneously throughout the year. Such conditions can be expected on the Ruwenzori Mountains in East Africa, and on Irian Jaya in New Guinea (Kaser and others, 1996a).

In the outer tropics, notable accumulation occurs only during the wet season. During the dry season, there is little or no accumulation, and ablation is also reduced. Because of the dry air, much of the available energy is consumed by sublimation, and therefore little remains for melting. This has been shown by Kaser and others (1990) through an analysis of ablation measurements from glaciers of the Cordillera Blanca, and by Wagnon and others (1999) through energy-balance investigations on Glaciar Zongo, Bolivian Cordillera Real. It is noteworthy that most of the tropical glaciers are found in the outer-tropical regime mainly because of the meridional lengthening of the austral summer ITCZ over South America (Fig. 1).

Under extreme subtropical conditions, as in southern Bolivia and northern Chile, almost all ablation can be presumed to result from sublimation (Knoche, 1931). The sparse accumulation is from sporadic precipitation which is distributed over the year and is related to either the ITCZ or the westerly frontal zone (e.g. Vuille and Ammann, 1997). The annual temperature variation increases with latitude, so the ablation season becomes slightly shorter than in the tropics.

Thus, two variables describe the principal differences between the three low-latitude glacier regimes and serve to distinguish them from mid-latitude conditions: (i) the ratio of melting to sublimation, and (ii) the duration of the ablation period. These two variables are vital components of any model which seeks to depict the characteristic differences of such glacier regimes.

\section{MODELLING THE VBP}

The VBP of a glacier is the variation of the specific mass balance with altitude (i.e. the vertical profile of specific mass balance). The VBP emphasizes the relation between a glacier and its climatic setting. The climatic setting is a combination of widely homogeneous regional factors which can be parameterized from variables of the free atmosphere, and local factors which are unique for each glacier. Both have been discussed and introduced in glacier climate models of varied sophistication (Kuhn, 1981, 1989; Oerlemans, 1989; Oerlemans and Hoogendoorn, 1989; Ohmura and others, 1992).

Here, the glacier-climate interaction is simplified to the regional climate variables since the aim of the model is to depict the characteristic differences between large-scale glacier regimes. A synthetic VBP is first modelled and calibrated for a mid-latitude glacier (Hintereisferner, Austrian Alps) from selected variables. The model is then exposed successively to inner-tropical, outer-tropical and subtropical conditions. The basic structure of the model is adopted from Kuhn's model describing the response of the ELA to climatic fluctuations (Kuhn, 1981, 1989).

The specific mass budget $b$ at any altitude $z$ on a glacier over a specific period is composed of the sum of specific accumulation $(c(z)$, positive) and specific ablation $(a(z)$, negative)

$$
b(z)=c(z)+a(z) \quad\left[\mathrm{kg} \mathrm{m}^{-2}\right] .
$$

The vertical mass-balance gradient is thus

$$
\frac{\mathrm{d} b}{\mathrm{~d} z}=\frac{\partial c}{\partial z}+\frac{\partial a}{\partial z} \quad\left[\mathrm{~kg} \mathrm{~m}^{-2} \mathrm{~m}^{-1}\right]
$$

with positive $z$ vertically upward. The differential of the specific balance is then

$$
\mathrm{d} b=\frac{\partial c}{\partial z} \mathrm{~d} z+\frac{\partial a}{\partial z} \mathrm{~d} z .
$$

Ablation at any given altitude results from the available heat flux per horizontal surface unit, $Q_{\mathrm{A}}$, in $\mathrm{J} \mathrm{m}^{-2} \mathrm{~d}^{-1}$, thus: 


$$
a(z)=-\tau(z) \frac{1}{L} Q_{\mathrm{A}}(z),
$$

where $L$ is the heat of fusion $\left(L_{\mathrm{M}}=0.334 \mathrm{MJ} \mathrm{kg}^{-1}\right)$ and/or sublimation $\left(L_{\mathrm{S}}=2.835 \mathrm{MJ} \mathrm{kg}^{-1}\right)$, and $\tau(z)$ is the duration of the ablation season at the given altitude, in days. Consistent with Equation (1), $a(z)$ is negative, so all heat fluxes toward the surface are positive. In a linear approximation, $\tau(z)$ can be calculated from a given $\tau\left(z_{\text {ref }}\right)$ at a reference altitude as

$$
\tau(z)=\tau\left(z_{\mathrm{ref}}\right)+\frac{\partial \tau}{\partial z} \mathrm{~d} z .
$$

The duration of the ablation period $\tau$ must be known in order to convert energy into mass-balance terms. It is not an entirely independent variable but should always be treated together with the mean energy flux over that period. If, hereinafter, $\tau$ is changed while the energy fluxes are kept constant, a constant daily mean of the energy fluxes over different time periods and at different altitudes is assumed for simplification.

The vertical ablation gradient at a given altitude $z$ is

$$
\left.\frac{\partial a}{\partial z}\right|_{z}=-\frac{\partial \tau}{\partial z} \frac{1}{L} Q_{\mathrm{A}}(z)-\tau(z) \frac{1}{L} \frac{\partial Q_{\mathrm{A}}}{\partial z} .
$$

Considering that $(1 / L) Q_{\mathrm{A}}(z)=a(z) / \tau(z)$, Equation (6) becomes

$$
\left.\frac{\partial a}{\partial z}\right|_{z}=-\frac{\partial \tau}{\partial z}\left[\frac{a(z)}{\tau(z)}\right]-\tau(z) \frac{1}{L}\left(\frac{\partial Q_{\mathrm{A}}}{\partial z}\right)
$$

For the large-scale regional objectives of this model, which is intended to calculate the shape but not the absolute position of the VBP, the following are assumed:

The sensible-heat flux is described by $C_{\mathrm{S}}\left[\partial\left(T_{\mathrm{a}}-T_{\mathrm{S}}\right) / \partial z\right]$, where $C_{\mathrm{S}}$ is the heat-transfer coefficient for turbulent exchange of sensible heat between atmosphere and glacier surface, in $\mathrm{MJ} \mathrm{m}^{-2} \mathrm{~d}^{-1}{ }^{\circ} \mathrm{C}^{-1}$. Under melting conditions, the term is reduced to $C_{\mathrm{S}} \partial T_{\mathrm{a}} / \partial z ; \partial T_{\mathrm{a}} / \partial z$ is the atmospheric lapse rate. Under non-melting conditions the vertical gradient of the surface temperature is $\partial T_{\mathrm{s}} / \partial z=\partial T_{\mathrm{a}} / \partial z$; thus the vertical gradient of the sensible-heat flux becomes 0 . The value of $C_{\mathrm{S}}$ is discussed below.

Similarly, the vertical gradient of the net longwave radiation is reduced to the incoming flux under melting conditions. The incoming longwave radiation is, using a linearized form of the Stefan-Boltzmann equation, $4 \varepsilon_{\mathrm{a}} \sigma(273.15)^{3} \partial T_{\mathrm{a}} / \partial z$, where $\varepsilon_{\mathrm{a}}$ is the emissivity of the atmosphere and $\sigma$ is the Stefan-Boltzmann constant. By analogy to the heat-transfer coefficient, the constant part of the equation is $4 \varepsilon_{\mathrm{a}} \sigma(273.15)^{3}=C_{\mathrm{R}}=0.28 \mathrm{MJ} \mathrm{m}^{-2} \mathrm{~d}^{-1}$ $\mathrm{K}^{-1}$ with $\varepsilon_{\mathrm{a}}=0.7$ and $\sigma=4.9 \times 10^{-9} \mathrm{MJ} \mathrm{m}^{-2} \mathrm{~d}^{-1} \mathrm{~K}^{-4}$. The vertical gradient of the incoming longwave radiation thus obtained matches well the measured values reported by Müller (1984). Again, if the surface is frozen, $\partial T_{\mathrm{a}} / \partial z=$ $\partial T_{\mathrm{s}} / \partial z$ and the vertical gradient of incoming longwave radiation is compensated by the gradient of longwave emission. Thus, no input to the model comes from net longwave radiation.

The vertical gradient of the global radiation, $\partial G / \partial z$, is 0 .

Mean values of albedo, $\alpha$, on snow and ice have been known for some time (e.g. Sauberer and Dirmhirn, 1952; Wagner, 1979). At the transient snowline, the albedo of a glacier surface changes more or less abruptly from low values on bare ice $\left(\alpha_{\text {ice }}\right)$ to the relatively high values of the snow surface $\left(\alpha_{\text {snow }}\right)$. If the snowline is assumed to rise more or less continuously, at a rate $\mathrm{d} z / \mathrm{d} t$, from the tongue to its highest position (equal to the ELA) during an ablation season of length $\tau$, the annually averaged vertical gradient of albedo is approximately

$$
\frac{\partial \alpha}{\partial z}=\frac{\alpha_{\text {snow }}-\alpha_{\text {ice }}}{\frac{\mathrm{d} z}{\mathrm{~d} t} \tau}
$$

Above the ELA, $\partial \alpha / \partial z=0$.

The contributions of melting and sublimation to ablation are described by the term

$$
F=\frac{1-f}{L_{\mathrm{M}}}+\frac{f}{L_{\mathrm{S}}},
$$

where

$$
f=\frac{Q_{\mathrm{L}}}{Q_{\mathrm{M}}+Q_{\mathrm{L}}} .
$$

$L_{\mathrm{M}}$ and $L_{\mathrm{S}}$ are the heat constants for fusion and sublimation, and $Q_{\mathrm{M}}$ and $Q_{\mathrm{L}}$ the heat fluxes consumed by melting and sublimation. It is stressed that this approach ignores a possible variation of the ratio $f$ with elevation. However, it allows for the consideration of sublimation as a crucial variable when comparing humid and dry climates.

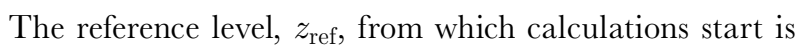
defined as the elevation at and above which $\partial a / \partial z=$ $0 \mathrm{~kg} \mathrm{~m}^{-2} \mathrm{~m}^{-1}$. This does not necessarily mean that $a=$ $0 \mathrm{~kg} \mathrm{~m}^{-2}$. From $z_{\text {ref }}$, calculations proceed upward $(z=+)$ and downward $(z=-)$. It is assumed that $\partial T_{\mathrm{s}} / \partial z=$ $\partial T_{\mathrm{a}} / \partial z$ above the mean $0^{\circ} \mathrm{C}(273.15 \mathrm{~K})$ level of the ablation period. Consequently, the vertical gradient of the sensibleheat flux becomes zero and the vertical gradient of the incoming longwave radiation is compensated by the gradient of longwave emission. $\partial \alpha / \partial z$ becomes zero above the ELA. Thus, ideally, $z_{\text {ref }}$, the $0^{\circ} \mathrm{C}$ level and the ELA should all be the same altitude. On the mid-latitude Hintereisferner, the mean ELA lies clearly below the mean $0^{\circ} \mathrm{C}$ level of the mean ablation period (from longterm ELA and temperature records in Kuhn and others (1979)). The same is true in the inner tropics (Kuhn, 1980; Ohmura and others, 1992). Hence, $z_{\text {ref }}$ is set equal to the altitude of the mean $0^{\circ} \mathrm{C}$ level for the VBP model of both the mid-latitude Hintereisferner and the inner-tropical glaciers. The area over which $\partial \alpha / \partial z>0$ is thereby extended up to the $0^{\circ} \mathrm{C}$ level, leading to an overestimate of the gradient in specific mass balance in this altitudinal step. In the subtropics, the ELA lies up to $1 \mathrm{~km}$ above the $0^{\circ} \mathrm{C}$ level (Kuhn, 1980; Ohmura and others, 1992), so $z_{\text {ref }}=$ ELA.

Thus, the vertical gradient in ablation at any altitude, $z=-$ (i.e. below the equilibrium line $(\mathrm{EL})$ ), is

$$
\left.\frac{\partial a}{\partial z}\right|_{z}=-\frac{\partial \tau}{\partial z} \frac{a(z)}{\tau(z)}-F \tau(z)\left(-G \frac{\partial \alpha}{\partial z}+C_{\mathrm{R}} \frac{\partial T_{\mathrm{a}}}{\partial z}+C_{\mathrm{S}} \frac{\partial T_{\mathrm{a}}}{\partial z}\right)
$$

where the contributions to the vertical gradient in the energy for ablation, $\partial Q_{\mathrm{A}} / \partial z$, are reduced to those from the vertical gradients of the net global radiation, the incoming longwave radiation and the sensible-heat flux. From Equa- 
tion (3), the change in specific mass balance between discrete altitude steps $\Delta z$, above and below any level $z$, is then

$$
\begin{aligned}
\Delta b & =\frac{\partial c}{\partial z} \Delta z \\
& -\left[\frac{\partial \tau}{\partial z} \frac{a(z)}{\tau(z)}-F \tau(z)\left(-G \frac{\partial \alpha}{\partial z}+C_{\mathrm{R}} \frac{\partial T_{\mathrm{a}}}{\partial z}+C_{\mathrm{S}} \frac{\partial T_{\mathrm{a}}}{\partial z}\right)\right] \Delta z
\end{aligned}
$$

\subsection{The VBP in the mid-latitudes}

Let us now calculate a VBP from climatic data and calibrate it with a measured profile. Both the climate data and the measured profile are from the Hintereisferner. Based on Kuhn (1979, 1981), Kuhn and others (1979), Wagner (1979) and some additional references mentioned below, the following model input data are representative for Hintereisferner under mass-equilibrium conditions:

The mean duration of the annual period of ablation at the altitude of the summer mean $0^{\circ} \mathrm{C}$ level (June-September) is $\tau_{\text {ref }}=100$ days. This is thought to be the number of days, not necessarily successively, during which ablation takes place.

The duration of the ablation period changes with the altitude at a rate of $\partial \tau / \partial z=-0.1$ day $\mathrm{m}^{-1}$.

Accumulation increases with altitude at a rate of $\partial c / \partial z=1 \mathrm{~kg} \mathrm{~m}^{-2} \mathrm{~m}^{-1}$.

The air temperature decreases with altitude at a rate of $\partial T_{\mathrm{a}} / \partial z=-0.0065^{\circ} \mathrm{C} \mathrm{m}^{-1}$.

At Hintereisferner, the ELA is about 100-150 m below the summer mean $0^{\circ} \mathrm{C}$ level. Because we do not have sufficient knowledge, annual ablation at the altitude of the summer $0^{\circ} \mathrm{C}$ level, $a\left(z_{\text {ref }}\right)$, is approximated by the ablation at the mean EL. This, in turn, is equal to the accumulation there, which is approximately $1600 \mathrm{~kg} \mathrm{~m}^{-2}$ at Hintereisferner. (Note that the effect of an inaccurate determination of $a\left(z_{\text {ref }}\right)$ on $\Delta b$ is small because $\partial \tau / \partial z$ is small.)

The mean daily amount of energy from global radiation is $G=20 \mathrm{MJ} \mathrm{m}^{-2} \mathrm{~d}^{-1}$.

Müller (1984) gives a compilation of measured albedo values for different Alpine glacier surfaces including Hintereisferner. According to his data the mean values for glacier ice and old snow are $\alpha_{\text {ice }}=0.27$ and $\alpha_{\text {snow }}=0.6$, respectively. It is further assumed that the snowline rises continuously from the glacier terminus $(2450 \mathrm{~m})$ to its location at the end of the ablation season (which is approximately the mean ELA $(3050 \mathrm{~m})$ ). Thus, $\mathrm{d} z / \mathrm{d} t=$ $5 \mathrm{~m} \mathrm{~d}^{-1}$ and $\partial \alpha / \partial z=0.00066 \mathrm{~m}^{-1}$. Even though the albedo changes little above the snowline, $\partial \alpha / \partial z$ is kept

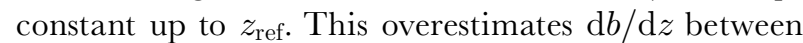
the ELA and $z_{\text {ref }}$, but the effect is minor when comparing the modelled and measured VBPs in Figure 2.

A sublimation rate of $150 \mathrm{~kg} \mathrm{~m}^{-2} \mathrm{a}^{-1}$ (Kaser, 1982, 1984) consumes about $20 \%$ of the energy available for ablation on the tongue of Hintereisferner; thus $f=0.2$.

While all variables and their variations discussed so far are well supported by measurements, the heat-transfer coefficient $C_{\mathrm{S}}$, being a bulk quantity to parameterize heat conductivity and turbulent exchange in the bound-

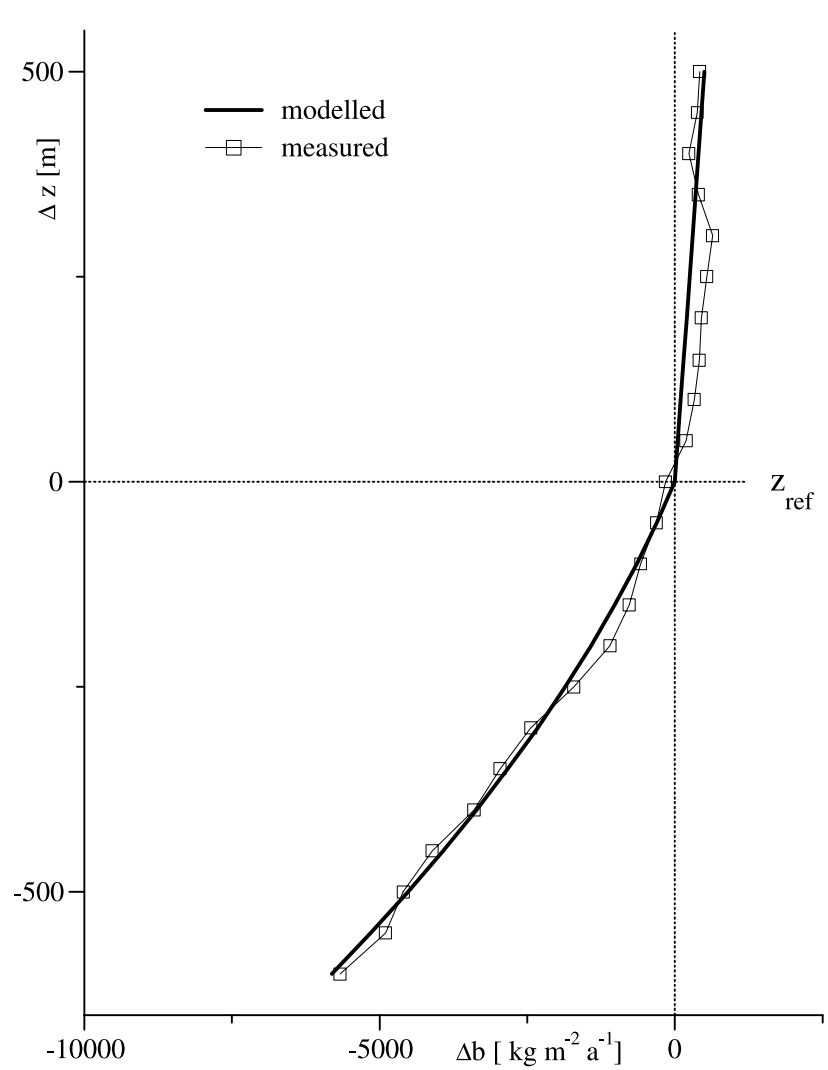

Fig. 2. A VBP calculated from climatic data for Hintereisferner (bold line). Above the reference altitude, $z_{\mathrm{ref}}$, the profile is influenced only by the accumulation gradient, whereas below $z_{\text {ref }}$ it is affected by both ablation and accumulation gradients. Note that $z_{\text {ref }}$ is at the $0^{\circ} \mathrm{C}$ level of the ablation period which, on Hintereisferner, is above the EL. The measured profile from the $1966 / 67$ balanced budget year $\left(\bar{b}=+20 \mathrm{~kg} \mathrm{~m}^{-2}\right.$ ) (thin line with symbols) is fit to the calculated profile by a parallel displacement along the coordinate axes.

ary layer between the surface of the glacier and the atmosphere, has been chosen to fit the model to the measured data. Values empirically obtained above different glacier surfaces range widely from 0.5 to 2.7 $\mathrm{MJ} \mathrm{m}^{-2} \mathrm{~d}^{-1} \mathrm{~K}^{-1} \quad$ Escher-Vetter, 1980; Funk, 1985; Schug, 1987; Kuhn, 1989; Tanzer, 1989). The value for a visual best fit to the shape of the curve in Figure 2 (but not its position) is $C_{\mathrm{S}}=1.7 \mathrm{MJ} \mathrm{m}^{-2} \mathrm{~d}^{-1} \mathrm{~K}^{-1}$, which is close to the arithmetic mean of the reported values. It must be noted that $C_{\mathrm{S}}$ not only parameterizes the complex processes of the sensible-heat exchange, but also compensates, to a certain extent, for the omitted changes with altitude.

The values of the variables are summarized in Table 1 .

Table 1. Variables and constants for the calculation of the mass-balance altitude profile in the mid-latitudes (Fig. 2)

$\partial c / \partial z(z=+)$
$\partial c / \partial z(z=-)$
$\partial \tau / \partial z$
$a\left(z_{\text {ref }}\right)$
$\tau\left(z_{\text {ref }}\right)$
$f$
$G$
$\partial \alpha / \partial z$
$\partial T_{\mathrm{a}} / \partial z$
$C_{\mathrm{S}}$

$$
\begin{gathered}
1 \mathrm{~kg} \mathrm{~m}^{-2} \mathrm{~m}^{-1} \\
1 \mathrm{~kg} \mathrm{~m}^{-2} \mathrm{~m}^{-1} \\
-0.1 \mathrm{~d} \mathrm{~m}^{-1} \\
1600 \mathrm{~kg} \mathrm{~m}^{-2} \mathrm{a}^{-1} \\
100 \mathrm{~d} \\
0.2 \\
20 \mathrm{MJ} \mathrm{m}^{-2} \mathrm{~d}^{-1} \\
0.00066 \mathrm{~m}^{-1} \\
-0.0065 \mathrm{~K} \mathrm{~m}^{-1} \\
1.7 \mathrm{MJ} \mathrm{m}^{-2} \mathrm{~d}^{-1} \mathrm{~K}^{-1}
\end{gathered}
$$


Table 2. Relative effects on $\Delta b$ of a $10 \%$ change in the variable in column 1, expressed as a percentage of the calculated value of $\Delta b$

\begin{tabular}{lccc}
\hline & Mid-latitudes & Inner tropics & Subtropics \\
\hline$\partial c / \partial z(z=-)$ & 1.2 & 0.4 & 3.9 \\
$\partial \tau / \partial z$ & 1.2 & - & - \\
$a\left(z_{\mathrm{ref}}\right)$ & 1.9 & - & - \\
$\tau\left(z_{\mathrm{ref}}\right)$ & 9.4 & 9.2 & 6.1 \\
$f$ & 2.3 & 2.0 & 46.0 \\
$G$ & 5.4 & 4.8 & 6.1 \\
$\partial \alpha / \partial z$ & 5.4 & 4.8 & 6.1 \\
$\partial T_{\mathrm{a}} / \partial z$ & 5.3 & 4.7 & - \\
$C_{\mathrm{S}}$ & 4.5 & 4.1 & - \\
\hline
\end{tabular}

Figure 2 compares the modelled VBP with the measured values from the balance year 1966/67, which was a year of nearly balanced mass budget (mean specific mass balance $\bar{b}=+20 \mathrm{~kg} \mathrm{~m}^{-2}$ ). Because the model provides the shape but not the absolute position of the VBP, the measured curve has been shifted along the coordinate axes to obtain a visual best fit to the position. The shapes of the curves agree well; both are characterized by a continuous decrease in the vertical mass-balance gradient with altitude.

Looking at the different terms in Equation (12), it is obvious that the contributions from the gradients of the sensible-heat flux and the shortwave net radiation to the ablation gradient are about an order of magnitude larger than that of the gradient of the incoming longwave radiation. Together with the factors $\tau$ and $f$, they are the predominant control on the ablation gradient. The accuracy of parameter values and their possible variations are, however, not sufficiently well known. Thus, in order to give an idea of the sensitivity of the model to different input variables, the effect on $\Delta b$ of a $10 \%$ change in each variable is calculated. The results, expressed as a percentage of the original calculated $\Delta b$, are shown in the first column in Table 2. The model is most sensitive to changes in $\tau(9.4 \%)$ followed by the shortwave radiation term, $G \partial \alpha / \partial z(5.4 \%), \partial T_{\mathrm{a}} / \partial z(5.3 \%)$ and $C_{\mathrm{S}}(4.5 \%)$. The effect of the other terms on $\Delta b$ is minor. The values in Table 2 are also reasonable estimates of the accuracy of most input variables. Exceptions are $\partial \alpha / \partial z$ and $C_{\mathrm{S}}$, the values of both of which are educated guesses. However, the strong correlation between the model results and the measured VBP allows the assumption that all input variables are within $10 \%$ of their true values. Assuming that the uncertainties in the different input variables are more likely to compensate each other than to accumulate, the accuracy of the modelled VBP is likely to be $\pm 5 \%$. Even though this is strictly true only for Hintereisferner, in the comparison and discussion to follow below, the above-modelled VBP is postulated to be typical for the midlatitudes.

\subsection{The VBP in the inner tropics}

For modelling the inner-tropical VBP, it is assumed that the ablation period is $\tau=365$ days a ${ }^{-1}$ everywhere on the glacier at and below the $z_{\text {ref. }}$ This implies that $\partial \tau / \partial z=0$ and allows simplification of Equation (12). This is the only change relative to the mid-latitude model. The resulting VBP is shown in Figure 3, in which the synthetic profile is compared to those measured on Irian Jaya glaciers and on Lewis Glacier, Mount Kenya, both of which are situated close to the Equator.

The Irian Jaya VBP is reported by Allison (1976) as an

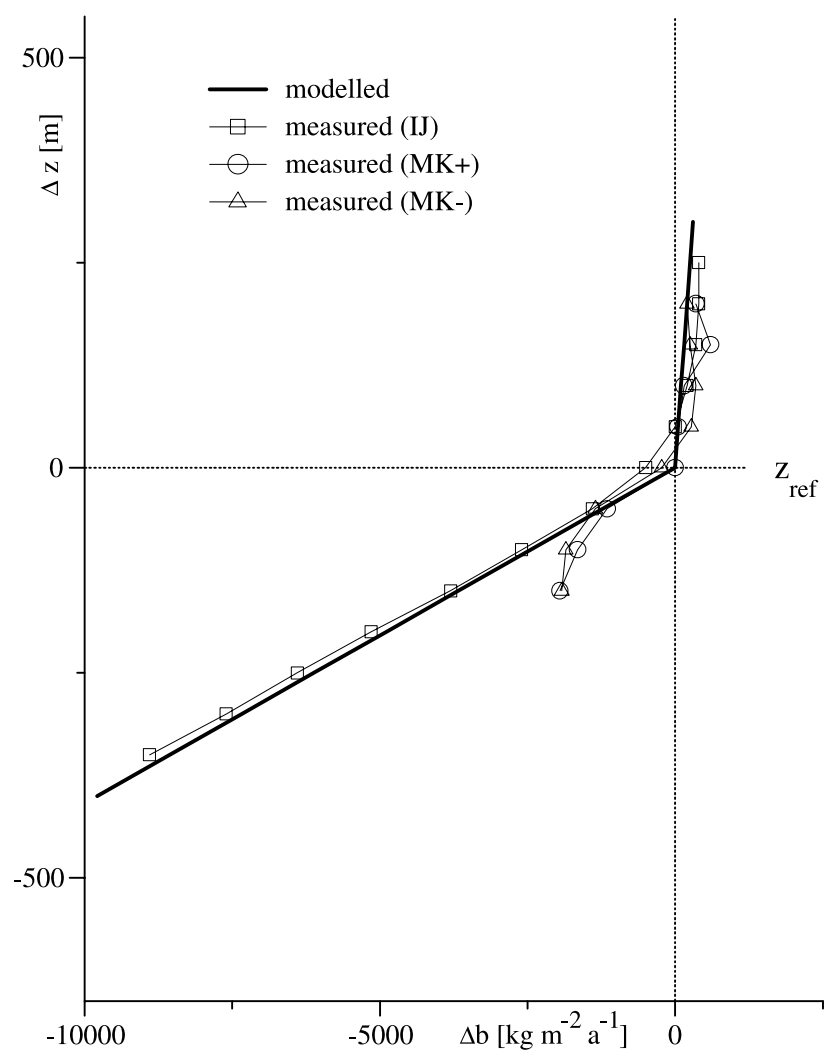

Fig. 3. Modelled (bold line) and measured (thin lines with symbols) VBPs of tropical glaciers. The measured profiles for Meren and Carstensz Glaciers, Irian Faya (If) and Lewis Glacier, Mount Kenya ( $M K$ ), are fit to the calculated profile by parallel displacements along the coordinate axes. $(M K+)$ is the VBP for the positive balance year 1988/89 ( $\bar{b}=$ $\left.+700 \mathrm{~kg} \mathrm{~m}^{-2}\right)$, and (MK-) the VBP for the negative balance year 1986/87 $\left(\bar{b}=-700 \mathrm{~kg} \mathrm{~m}^{-2}\right)$. Note that $z_{\mathrm{ref}}$ is at the $0^{\circ} \mathrm{C}$ level which is, on inner-tropical glaciers, above the EL.

average of measurements on Carstensz $\left(0.9 \mathrm{~km}^{2}\right)$ and Meren Glaciers $\left(1.9 \mathrm{~km}^{2}\right)$ and dates from 1972 . The annual values for the lowest $200 \mathrm{~m}$ in altitude were extrapolated by the authors from 3 months of observation. The specific mean balances were $\bar{b}=-60 \mathrm{~kg} \mathrm{~m}^{-2}$ on Carstensz Glacier and $\bar{b}=-510 \mathrm{~kg} \mathrm{~m}^{-2}$ on Meren Glacier. The mean value of both glaciers, weighted with respect to their relative surface areas, is $\bar{b}=-374 \mathrm{~kg} \mathrm{~m}^{-2}$. Thus the mass budget is far from being balanced.

The mass-balance record for Lewis Glacier $\left(0.24 \mathrm{~km}^{-2}\right)$ starts in 1971 (Hastenrath, 1984, 1991; Hastenrath and others, 1989), but there are no data for a year of balanced mass budget. Since theVBPs have very similar forms for different years, only two curves, one from 1986/87 with $\bar{b}=-770 \mathrm{~kg} \mathrm{~m}^{-2}$ and one from 1988/89 with $\bar{b}=+770 \mathrm{~kg} \mathrm{~m}^{-2}$, are shown in Figure 3 as examples. The sudden increase in the slope of the VBP on the lowest part of the tongue of Lewis Glacier is probably a result of local microclimatological influences.

Simply changing $\tau$ yields a modelled VBP that fits measured VBPs almost perfectly. In contrast, to obtain this difference between mid-latitude and tropical VBPs by changing $G, \partial \alpha / \partial z$ or $\partial T_{\mathrm{a}} / \partial z$, the first two must be multiplied by a factor of 6 and the latter by 7 , both of which are absolutely unrealistic.

One might assume that in the constantly humid inner tropics there is no sublimation so $f$ becomes 0 . The effect on the VBP could be compensated for by changing the lapse 
rate from $-0.0065 \mathrm{~K} \mathrm{~m}^{-1}$ to $-0.0042 \mathrm{~K} \mathrm{~m}^{-1}$, by reducing the global radiation to $G=13 \mathrm{MJ} \mathrm{m}^{-2} \mathrm{~d}^{-1}$ or by reducing $\partial \alpha / \partial z$ to $0.00043 \mathrm{~m}^{-1}$. The latter could be explained by the fact that the snowline does not rise more or less continuously with time from the terminus to the EL during an ablation season as it does in the mid-latitudes, but rises several times, in steps, during the year. The required values of lapse rate and global radiation are, as a mean, unrealistically low even for humid conditions. If, however, all three of the variables were reduced by $10 \%$, the VBP would be consistent with that reported from Irian Jaya.

Again, the sensitivity of the model is tested by changing each variable by $10 \%$ and looking at the effect on $\Delta b$ (Table 2, second column). Although the inner-tropical VBP is less sensitive than that in the mid-latitude, the ranking of the different variables is the same. Assuming a $10 \%$ accuracy of the variables, the accuracy of the inner-tropical VBP is, as in the mid-latitudes, about $5 \%$.

In Kaser (1995) and Kaser and others (1996a) a snow/rain transition zone of $400 \mathrm{~m}$ in altitude below the $0^{\circ} \mathrm{C}$ level was discussed. This would flatten the lower part of the tropical VBP due to an increased gradient of accumulation. Recent field observations in the outer-tropical Cordillera Blanca during the humid season have shown that precipitation falls either as snow or as rain over the entire surface of the tongues. Thus, a gradient of accumulation equal to that in the Alps may remain a best guess. Note also that doubling $\partial c / \partial z$ would affect the VBP by only $4 \%$.

With the assumption of constant ablation conditions throughout the year, aVBP is generated which is clearly different from that in the mid-latitudes and shows the basic characteristics of a tropical VBP: compared with the midlatitudes, the balance gradient below the $0^{\circ} \mathrm{C}$ level is constant and markedly steeper, and the change to a small balance gradient in the accumulation zone is quite pronounced. It should be noted that if any ablation gradient above the $0^{\circ} \mathrm{C}$ level were allowed in the model, or if $\partial \alpha / \partial z$ exponentially approaches $0 \mathrm{~m}^{-1}$ between ELA and $z_{\text {ref }}$, the sharp change in the tropical VBP would be somewhat smoother and thus closer to the measured VBPs.

\subsection{The VBP in the subtropics}

There is little general information about glaciers in extremely dry subtropical climates, and no mass-balance measurements. Knoche (1931) reports exceptionally high sublimation values derived from climate records in northern Chile. Indeed, sublimation can be responsible for all of the ablation. Under such conditions, surface temperatures are kept below freezing much of the time, and the ELA is high above the $0^{\circ} \mathrm{C}$ level (Kuhn, 1980; Ohmura and others, 1992). The (negative) surface temperature, $T_{\mathrm{S}}$, decreases further with increasing altitude, so $\partial T_{\mathrm{S}} / \partial z$ is again approximately equal to $\partial T_{\mathrm{a}} / \partial z$, and vertical gradients of both sensible-heat flux and longwave radiation budget are thus zero. Consequently, the respective energy terms in Equation (12) are negligible, as a first approximation. As a consequence, the energy gradient is calculated with only $G$ and $\partial \alpha / \partial z$. This creates the possibility of setting $z_{\text {ref }}$ equal to the ELA, above which $\partial \alpha / \partial z$ becomes 0 . The ablation gradient is additionally determined by the factors $f$ and $\tau$. None of the input variables is reasonably known, and, besides sensitivity analysis, only an educated guess can be offered:

Under subtropical conditions the sublimation/melting ratio is set as $f=1$ and $\tau$ is set as 300 days $\mathrm{a}^{-1}$. The latter takes the increasing latitude into account, and the accompanying increasing seasonality of insolation. In addition, sporadic snowfalls may interrupt ablation for several consecutive days over the entire glacier. Under such circumstances, a possible but very small value of $\partial \tau / \partial z$ is neglected. During fieldwork on several glaciers in the Alps and in the Andes, I have observed that the glacier ice surface appears distinctly brighter under sublimation conditions than under strong melting conditions. This is because dry glacier surfaces provide considerable backscattering of solar radiation, due to the presence of dry pores. If, consequently, a higher albedo for ice is used in Equation (8), $\partial \alpha / \partial z$ becomes smaller. A value of $\partial \alpha / \partial z=$ $0.0005 \mathrm{~m}^{-1}$ is proposed, although it is difficult to approximate any albedo gradient. In addition, global radiation may reach values of $G=30 \mathrm{MJ} \mathrm{m}^{-2} \mathrm{~d}^{-1}$ in the subtropics. Inserting these

\section{mid-latitudes}

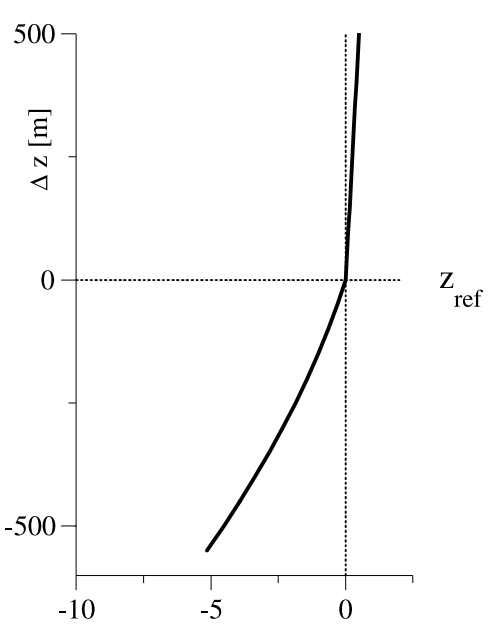

subtropics

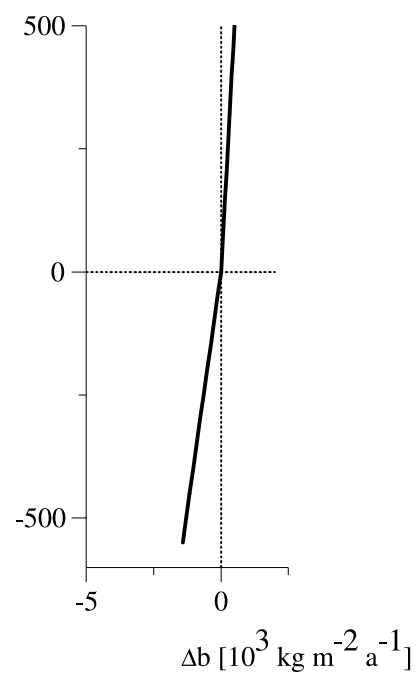

inner tropics

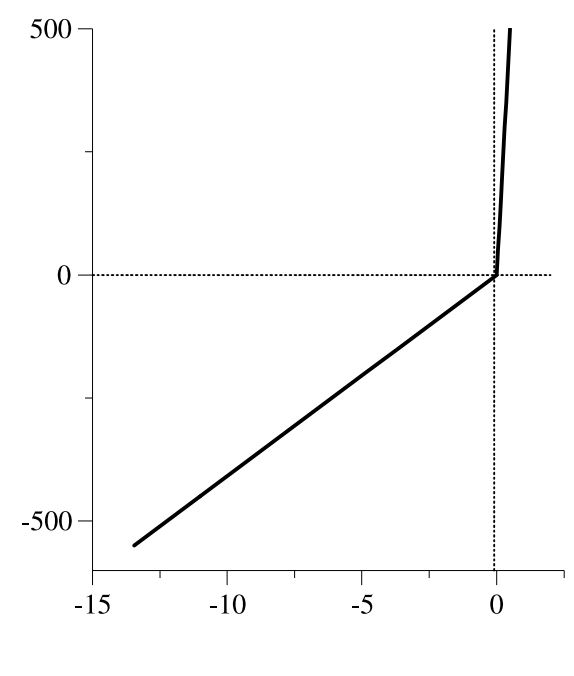

Fig. 4. Modelled VBPs for mid-latitude, subtropical and inner-tropical glacier regimes. Note that $z_{\mathrm{ref}}$ is at the $0^{\circ} \mathrm{C}$ level for the mid-latitude and inner-tropical glaciers but is at the EL for the subtropical glaciers. 
values into the model, $\mathrm{d} b / \mathrm{d} z(z=-)$ becomes almost 9.5 times smaller than it is in the tropics.

The effect on $\Delta b$ of changing all variables in question by $10 \%$ is shown in the third column of Table 2 . The most influential term by far is the sublimation/melting ratio, $f$, which causes a $46 \%$ variation whereas the effect of the other terms is, individually, $\leq 6.1 \%$. No information is available regarding the accuracy of determinations of $f$ in the subtropics, but this example shows how sensitive subtropical glaciers are to changes in air humidity. The subtropical VBP is compared to the VBPs of the mid-latitudes and the tropics in Figure 4. The subtropical VBP has the least change of $b$ with $z$ as a result of the extremely dry circumstances.

So far, the modelling has shown that the duration of the ablation period is the crucial variable distinguishing lowlatitude from mid-latitude glacier regimes, and that sublimation markedly distinguishes the subtropical regime from the inner-tropical one. Changes of the other variables within realistic ranges are of secondary importance.

\subsection{The VBP in the outer tropics}

It has been mentioned above that the outer tropics are characterized by tropical conditions during the humid season and by subtropical conditions during the dry season. This not only compels one to look at the outer tropics from two different points of view, but also provides, indirectly, the possibility of examining the subtropical model assumptions.

Modelled VBPs were calculated with the tropical model for the humid season, and with the subtropical model for the dry season, by changing $\tau$ to 212 and 153 days a ${ }^{-1}$, respectively. These values correspond to the situation in the outer-tropical Cordillera Blanca. There, the climate shows almost no annual temperature variation and has one humid season, OctoberApril (212 days), and one dry season, May-September (153 days), which are clearly distinguished from each other (Kaser and others, 1990). The so calculated VBPs are shown as bold lines in Figure 5 .

Mass-balance measurements were carried out by members of the Peruvian hydropower company HIDRANDINA S.A. on Glaciar Uruashraju, southern Cordillera Blanca, to name one example, in the 1970s and 1980s. VBPs from both the humid and dry seasons are reported by Kaser and others (1990). These circumstances are typical for the outer tropics and are responsible for the basic conditions of the respective glacier regimes, as discussed above. Figure $5 \mathrm{a}$ shows the measured profiles for Glaciar Uruashraju for each season, and Figure $5 \mathrm{~b}$ the same profiles but grouped together in order to compare them with the synthetic profiles. Measurements were made only on the tongue in most cases and never cover the entire glacier. With the exception of the 1982/83 El Niño year (open circles in Fig. 5), the modelled VBPs correspond well with the measured VBPs for both seasons. Even if the

\section{Uruashraju - humid season}
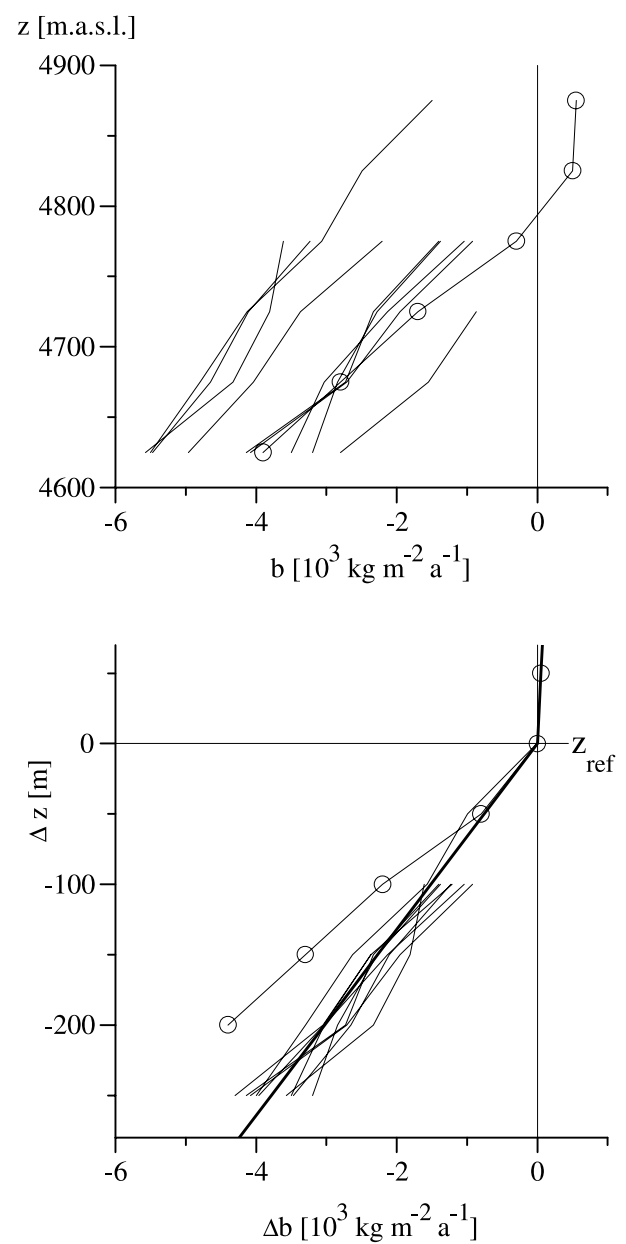

\section{Uruashraju - dry season}
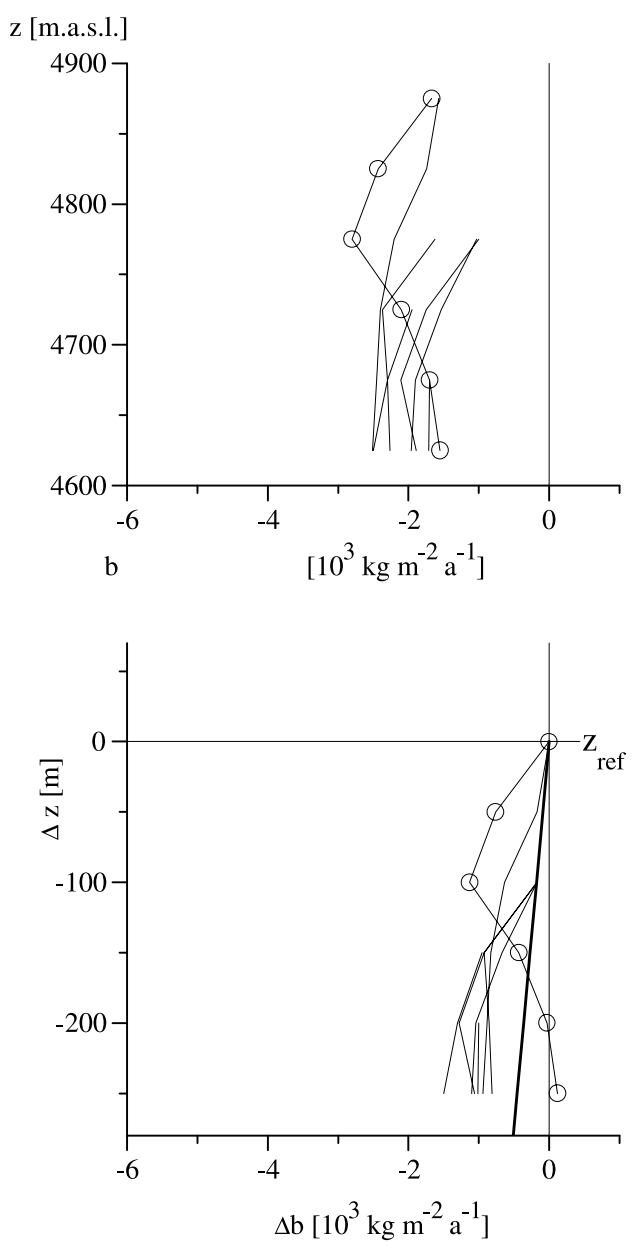

Fig. 5. VBPs, measured at Glaciar Uruashraju, and comparison with the modelled inner-tropical and subtropical profiles ( bottom) for each season. Circles indicate the profiles in the 1982/83 El Niño year. Note that $z_{\mathrm{ref}}$ is at the $0^{\circ} \mathrm{Clevel}$ for the humid season and is at the EL for the dry season. For detailed discussion see text. 
modelled VBP for the dry season seems to deviate from the measured ones at first glance, a closer look shows that the gradient is correct for most altitude zones. With minor deviations from the postulated conditions, well within the uncertainty in the data, the model can easily reproduce most of these measured profiles. In addition to these results, investigations by Wagnon and others (1999) carried out at the mean ELA on the outer-tropical Glaciar Zongo, strongly support the reliability of the model. They show that, of the energy-balance terms, only the latent-heat flux changes fundamentally with the season. Whereas it is minor during the humid season, it consumes almost the entire energy surplus from the radiation balance input during the dry season. Because the reaction of glaciers to changes in the climate variables varies seasonally, the respective lengths of the alternating seasons due to changes in both the geographical setting of the glacier and long-term climate fluctuations have an important impact on the glacierclimate relation in the outer tropics. The shorter one of the seasons becomes, the more the annual VBP adopts the other season's character. Kull (1999) and Kull and Grosjean (2000) have shown that this concept is useful in investigating paleocirculation patterns.

The 1982/83 El Niño year shows conspicuously different VBP profiles on Glaciar Uruashraju. The 1982/83 wet season is indicated by a distinctly stronger balance gradient all over the tongue, and the dry season shows an inverse balance profile with almost no gradients in the lowest parts and a relatively strong gradient in the higher part of the tongue. Wagnon (1999) examined the 1997/98 El Niño-Southern Oscillation (ENSO) event under outer-tropical conditions at the mean EL of Glaciar Zongo. During this El Niño year, the noticeably higher ablation was mainly due to: (1) low surface albedo during the wet season owing to markedly lower precipitation, and (2) almost non-existent sublimation because of high air humidity during the dry season. A. Ames from Huaraz, Peru (personal communication, 1999), reports also that precipitation fell exclusively as rain all over the glacier tongues in the Cordillera Blanca during the entire 1997/98 ENSO period. These observations indicate clearly different conditions during ENSO events when the "ideal" subtropical model assumptions must be modified. The impact of such ENSO conditions on the VBPs cannot be adequately explained without the support of further field measurements.

\section{SENSITIVITY OF EL TO GLIMATE VARIATIONS}

In addition to the VBP, the ELA is the most suitable parameter for interpreting glacier responses to climate variations. Its sensitivity to climate variations depends on the gradients of the mass-balance terms at the respective altitudes. In order to study the sensitivity of the ELs under the different conditions, their mean positions in the respective VBPs must be determined. For the mid-latitudes, the example of Hintereisferner indicates that the EL is somewhat below the $0^{\circ} \mathrm{C}$ level of the ablation period and thus below $z_{\text {ref }}$ (data taken from Kuhn and others (1979) indicate that the EL is about $120 \mathrm{~m}$ below the summer $0^{\circ} \mathrm{C}$ level). In the inner tropics, the EL lies clearly below the $0^{\circ} \mathrm{C}$ level (Kuhn, 1980; Ohmura and others, 1992). Thus, the gradient below $z_{\text {ref }}$ is decisive for EL sensitivity studies. This is different for the subtropics, where the EL is set equal to $z_{\text {ref }}$ as a model assumption. Still, at the EL $\partial \alpha / \partial z=0 \mathrm{~m}^{-1}$ so only the accumulation gradient affects the shift of the ELA. Yet, for EL sensitivity studies in the subtropics the model is clearly overtaxed at this point since the inaccuracies of the model assumptions crucially influence the result. Both a different accumulation gradient and a possible, albeit small, ablation gradient above $z_{\text {ref }}$ would markedly change the sensitivity of the ELA. Consequently, this discussion will concern only the inner tropics for comparison with the mid-latitudes. The gradients in question can be obtained from the respective idealized model as follows:

for the mid-latitudes: $\mathrm{d} b / \mathrm{d} z=7.4 \mathrm{~kg} \mathrm{~m}^{-2} \mathrm{~m}^{-1}( \pm 5 \%)$ taken as a mean between $z=-100$ and $z=-150 \mathrm{~m}$.

for the inner tropics: $\mathrm{d} b / \mathrm{d} z=24.5 \mathrm{~kg} \mathrm{~m}^{-2} \mathrm{~m}^{-1}( \pm 5 \%)$ being constant at $z=-$.

A useful model for studying the sensitivity of the EL to climate variations, presented by Kuhn $(1980,1989)$, is based on the following relation: if $\delta c$ and $\delta Q$ are small changes, or perturbations, in accumulation and heat balance, these variations can be compensated through changes in $\Delta h$ of the ELA along the vertical gradients of the respective variables:

$$
\frac{\partial c}{\partial z} \Delta h+\delta c=\frac{\tau}{L}\left(\frac{\partial Q}{\partial z} \Delta h+\delta Q\right)
$$

Kuhn $(1980,1989)$ has discussed in detail the validity, the sensitivity and the possible relation between the variables in this type of model. If it is assumed that the altitudinal changes, $\partial / \partial z$, of $\tau, G(1-\alpha)$, the longwave irradiance and latent heat can be omitted in the respective range of $\Delta h$, and if the allocation to melting and/or sublimation is provided again by the factor $f$, the equation becomes

$$
\begin{aligned}
\frac{\partial c}{\partial z} \Delta h+\delta c=F \tau & \{\delta[G(1-\alpha)] \\
+ & \left.C_{\mathrm{S}}\left(\frac{\partial T_{\mathrm{a}}}{\partial z} \Delta h+\delta T_{\mathrm{a}}\right)+C_{\mathrm{R}} \delta T_{\mathrm{a}}\right\}
\end{aligned}
$$

Note that variations in the shortwave radiation balance can be caused by changes in either the albedo or the global radiation or both. This model allows examination of different climate variations as if each were solely responsible for an observed or reconstructed shift of the EL. In turn, a possible rise of the EL, caused by a postulated variation of a climate variable, can be calculated. For both the mid-latitude and the inner-tropical regimes, Table 3 shows the values of $\Delta h$ caused by given climatic perturbations under the assumption that they each appear alone.

Compared with the mid-latitudes, the values depicted in Table 3 show that, in the humid inner tropics, the reaction of the EL to changes in accumulation is distinctly weaker, whereas the reaction to changes in net shortwave radiation and to changes in air temperature is higher. The values in Table 4 show how sensitively the model reacts if the input variables are each changed by $10 \%$. (Note that for $f$ the

Table 3. The change in ELA ( $m$ ) caused by given individual perturbations, which act alone

Mid-latitudes

Inner tropics

$\begin{array}{lrr}\delta T_{\mathrm{a}}=1 \mathrm{~K} & 131 & 182 \\ \delta c=-100 \mathrm{~kg} \mathrm{~m}^{-2} \mathrm{a}^{-1} & 27 & 8 \\ \delta[G(1-\alpha)]=1 \mathrm{MJ} \mathrm{m}^{-2} \mathrm{~d}^{-1} & 66 & 92\end{array}$


Table 4. Percentage of the modelled shift of the EL due to a $10 \%$ uncertainty of each input variable for different model runs. Note that the uncertainty of $f$ is $10 \%$ of its entire range

\begin{tabular}{|c|c|c|c|c|c|c|c|}
\hline \multirow[b]{2}{*}{$\begin{array}{c}\text { Input } \\
\text { variable }\end{array}$} & \multirow[b]{2}{*}{$\begin{array}{l}\text { Uncer- } \\
\text { tainty }\end{array}$} & \multicolumn{2}{|c|}{$\begin{array}{l}\text { Model run } \\
\Delta h\left(\delta T_{\mathrm{a}}\right)\end{array}$} & \multicolumn{2}{|c|}{$\begin{array}{l}\text { Model run } \\
\Delta h(\delta c)\end{array}$} & \multicolumn{2}{|c|}{$\begin{array}{c}\text { Model run } \\
\Delta h\{\delta[G(1-\alpha)]\}\end{array}$} \\
\hline & & $\begin{array}{c}\text { Mid- } \\
\text { latitudes }\end{array}$ & $\begin{array}{l}\text { Inner } \\
\text { tropics }\end{array}$ & $\begin{array}{c}\text { Mid- } \\
\text { latitudes }\end{array}$ & $\begin{array}{l}\text { Inner } \\
\text { tropics }\end{array}$ & $\begin{array}{c}\text { Mid- } \\
\text { latitudes }\end{array}$ & $\begin{array}{l}\text { Inner } \\
\text { tropics }\end{array}$ \\
\hline$\tau$ & $10 \%$ & 3 & 1 & 7 & 10 & 3 & 1 \\
\hline$f$ & 0.1 & 3 & 1 & 8 & 9 & 3 & 1 \\
\hline$C_{\mathrm{S}}$ & $10 \%$ & 1 & 1 & 7 & 8 & 7 & 8 \\
\hline$\partial c / \partial z$ & $10 \%$ & 3 & 1 & 3 & 1 & 3 & 1 \\
\hline$\partial T_{\mathrm{a}} / \partial z$ & $10 \%$ & 8 & 9 & 8 & 9 & 8 & 9 \\
\hline
\end{tabular}

uncertainty is not $10 \%$ of the starting value, which would be 0 for the inner tropics, but $10 \%$ of the entire range. Thus this result is not necessarily comparable with that for the other uncertainties.) A $10 \%$ uncertainty in $\tau$ is quite unlikely for the inner tropics, so the effects that have most influence on the ELA are those resulting from uncertainties in the lapse rate for all model runs and for $C_{\mathrm{S}}$ in the accumulation and radiation runs. Still, all are below $10 \%$.

\section{SUMMARY AND CONGLUSIONS}

Glaciers in low latitudes are climate indicators in large-scale zonal regions: the inner tropics, the outer tropics and the subtropics. The low latitudes are defined by low thermal seasonality which leads to continuous ablation and a constant $0^{\circ} \mathrm{C}$ level during the whole year. These regions are also defined by the global circulation patterns of the ITC and the trade winds, including their seasonal oscillation, which cause distinct spatial and temporal differences in humidity. On the one hand, this leads to different durations and amounts of accumulation, and on the other, changing air humidity alters the ratio of melting and sublimation, and thus the way in which energy is used for ablation. Studies of glacier-climate interactions have to take these peculiarities of low-latitude climate regimes into account. They determine both the form of the VBP and the sensitivity of the ELA to climate variations.

The model presented herein allows analysis of the characteristic variables in the different climate regimes of the low latitudes. Compared with the mid-latitudes, the VBP in the inner tropics has a steeper gradient in the ablation zone and a marked change toward weak gradients above the $0^{\circ} \mathrm{C}$ level. The subtropical profile has a distinctly gentler gradient. The duration of the ablation season is the crucial variable that, when changed, causes the difference between the mid-latitude and the inner-tropical profiles, and the ratio of melting to sublimation, when changed, is that which causes the difference between the inner tropics and the subtropics. As a consequence of the respective mass-balance gradients, the sensitivity of the EL to climate variations is, compared with the mid-latitudes, generally weaker in the inner tropics. However, the model is overtaxed when applied to the ELA sensitivity in the subtropics.

In summary, the glaciers of the humid inner tropics are considered to be most sensitive to variations in air temperature, whereas those of the dry subtropics are most sensitive to changes in air humidity, not only in terms of accumulation, but even more so when the ratio of melting to sublimation is considered.
The outer tropics, where most low-latitude glaciers are situated, are a transitional zone where tropical climate dominates during the humid season and subtropical conditions prevail during the dry season. This is important for the interpretation of glacier fluctuations. At first glance, integrated over the entire year, the outer-tropical VBPs may seem similar to those of the mid-latitudes. Looking at the different seasons separately, however, it becomes obvious that glaciers in the outer tropics obey different rules. Since the duration and the intensity of the different seasons varies with distance from the inner tropics, with lee- and windward effects and with the grade of continentality, and also changes with the long-term fluctuations of the global atmospheric circulation patterns, it is important to consider these issues when analyzing glacier-climate interactions in the outer tropics.

\section{ACKNOWLEDGEMENTS}

I wish to thank C. Georges for his support during many discussions and with the preparation of the figures, and I am very grateful to $\mathrm{M}$. Kuhn and two anonymous referees and the scientific editor R. LeB. Hooke for their constructive criticisms and suggestions. This research was supported by the Austrian Science Foundation (FWF) grant No. P13567-GEO.

\section{REFERENGES}

Allison, I. 1976. Glacier regimes and dynamics. In Hope, G. S., J. A. Peterson, U. Radok and I. Allison, eds. The equatorial glaciers of New Guinea: results of the 1971-1973 Australian Universities' expeditions to Irian Faya. Rotterdam, A. A. Balkema, 39-58.

Broecker, W. S. 1997. Mountain glaciers: records of atmospheric water vapor content? Global Biogeochem. Cycles, 11 (4), 589-597.

Escher-Vetter, H. 1980. Der Strahlungshaushalt des Vernagtferners als Basis der Energiehaushaltsberechnung zur Bestimmung der Schmeltzwasserproduktion eines Alpengletschers. München, Universität München. Meteorologisches Institut. (Wissenschaftliche Mitteilungen 39.)

Funk, M. 1985. Räumliche Verteilung der Massenbilanz auf dem Rhonegletscher und ihre Beziehung zu Klimaelementen. Zürcher Geogr. Schr. 24.

Hastenrath, S. 1984. The glaciers of equatorial East Africa. Dordrecht, etc., D. Reidel Publishing Co.

Hastenrath, S. 1991. Glaciological studies on Mount Kenya 1971-83-91. Madison, WI, University of Wisconsin. Department of Meteorology.

Hastenrath, S. 1995. Glacier recession on Mount Kenya in the context of the global tropics. Bull. Inst. Fr. Étud. Andines (Lima), 24(3), 633-638.

Hastenrath, S. and P. D. Kruss. 1992. The dramatic retreat of Mount Kenya's glaciers between 1963 and 1987: greenhouse forcing. Ann. Glaciol., 16, 127-133.

Hastenrath, S., R. Rostom and R. A. Caukwell. 1989. Variations of Mount Kenya's glaciers, 1963-87. Erdkunde, 43(3), 202-210.

Hostetler, S. W. and P. U. Clark. 2000. Tropical climate at the Last Glacial Maximum inferred from glacier mass-balance modeling. Science, 290(5497), 1747-1750.

Kaser, G. 1982. Measurements of evaporation from snow. Arch. Meteorol. Geophys. Bioklimatol., Ser. B, 30(4), 333-340.

Kaser, G. 1984. Über die Verdunstung auf dem Hintereisferner. Z Gletscherkd. Glazialgeol., 19(2), 1983, 149-162.

Kaser, G. 1995. Some notes on the behavior of tropical glaciers. Bull. Inst. Fr. Étud. Andines (Lima), 24(3), 671-681.

Kaser, G. 1999. A review of the modern fluctuations of tropical glaciers. Global Planet. Change, 22(1-4), 93-103.

Kaser, G. and C. Georges. 1997. Changes of the equilibrium-line altitude in the tropical Cordillera Blanca, Peru, 1930-50, and their spatial variations. Ann. Glaciol., 24, 344-349.

Kaser, G. and B. Noggler. 1991. Observations on Speke Glacier, Ruwenzori Range, Uganda. F. Glaciol., 37(127), 313-318.

Kaser, G., A. Ames and M. Zamora. 1990. Glacier fluctuations and climate in the Cordillera Blanca, Peru. Ann. Glaciol., 14, 136-140.

Kaser, G., S. Hastenrath and A. Ames. 1996a. Mass balance profiles on tropical glaciers. Z. Gletscherkd. Glazialgeol., 32, Part 2, 75-81.

Kaser, G., C. Georges and A. Ames. 1996b. Modern glacier fluctuations in the Huascarán-Chopicalqui Massif of the Cordillera Blanca, Perú. Z. 
Gletscherkd. Glazialgeol., 32, Part 2, 1995, 91-99.

Klein, A. G., G. O. Seltzer and B. L. Isacks. 1999. Modern and last local glacial maximum snowlines in the central Andes of Peru, Bolivia and northern Chile. Quat. Sci. Rev., 18, 63-84.

Knoche, W. 1931. Über den Einfluß der Verdunstung auf die Vergletscherung. Z. Gletscherkd., 19(1-3), 18-27.

Kuhn, M. 1979. On the computation of heat transfer coefficients from energy-balance gradients on a glacier. f. Glaciol., 22(87), 263-272.

Kuhn, M. 1980. Vergletscherung, Nullgradgrenze und Niederschlag in den Anden. Fahrbuch des Sonnblick-Vereines 1978-1979, 1-13.

Kuhn, M. 1981. Climate and glaciers. International Association of Hydrological Sciences Publication 131 (Symposium at Canberra 1979 - Sea Level, Ice and Climatic Change), 3-20.

Kuhn, M. 1989. The response of the equilibrium line altitude to climatic fluctuations: theory and observations. In Oerlemans, J., ed. Glacier fluctuations and climatic change. Dordrecht, etc., Kluwer Academic Publishers, 407-417.

Kuhn, M., G. Kaser, G. Markl, H. Wagner and H. Scheider. 1979. 25 Jahre Massenhaushaltsuntersuchungen am Hintereisferner. Innsbruck, Universität Innsbruck. Institut für Meteorologie und Geophysik.

Kull, G. 1999. Modellierung paläoklimatischer Verhältnisse basierend auf der jungpleistozänen Vergletscherung in Nordchile - ein Fallbeispiel aus den Nordchilenischen Anden. Z. Gletscherkd. Glazialgeol., 35(1), 35-64.

Kull, C. and M. Grosjean. 2000. Late Pleistocene climate conditions in the north Chilean Andes drawn from a climate-glacier model. 7. Glaciol., 46(155), 622-632

Müller, H. 1984. Zum Strahlungshaushalt im Alpenraum. Zürich, Eidgenössischen Technischen Hochschule Zürich. Versuchsanstalt für Wasserbau, Hydro- logie und Glaziologie. (Mitteilungen 71.)

Oerlemans, J. 1989. On the response of valley glaciers to climatic change. In Oerlemans, J., ed. Glacier fluctuations and climatic change. Dordrecht, etc., Kluwer Academic Publishers, 353-371.

Oerlemans, J. and N. C. Hoogendoorn. 1989. Mass-balance gradients and climatic change. f. Glaciol., 35(121), 399-405.

Ohmura, A., P. Kasser and M. Funk. 1992. Climate at the equilibrium line of glaciers. F. Glaciol., 38(130), 397-411.

Sauberer, F. and I. Dirmhirn. 1952. Der Strahlungshaushalt horizontaler Gletscherflächen auf dem hohen Sonnblick. Geogr. Ann., 34(3-4), 261-290.

Schug, H.-J. 1987. Der Schwarzmilzferner. Meteorologisch-glaziologische Untersuchung an einem Kleingletscher in den Allgäuer Alpen. (Diplomarbeit, Universität Innsbruck.)

Tanzer, G. 1989. Berechnung des Wärmehaushaltes an der Gleichgewichtslinie des Hintereisferners. (Diplomarbeit, Universität Innsbruck.)

Thompson, L. G. and 7 others. 1995. Late glacial stage and Holocene tropical ice core records from Huascarán, Peru. Science, 269(5220), 46-50.

Vuille, M. and C. Ammann. 1997. Regional snowfall patterns in the high, arid Andes (South America). Climatic Change, 36, 413-423.

Wagner, H. P. 1979. Strahlungshaushaltsuntersuchungen an einem Östalpengletscher während der Hauptablationsperiode. Teil 1. Kurzwellige Strahlung. Arch. Meteorol. Geophys. Bioklimatol., Ser. B, 27 (4), 297-324.

Wagnon, P. 1999. Analyse du bilan d'énergie d'un glacier tropical: application à la relation glacier-climat. (Thèse de doctorat, Université Joseph Fourier - Grenoble I.

Wagnon, P., P. Ribstein, G. Kaser and P. Berton. 1999. Energy balance and runoff seasonality of a Bolivian glacier. Global Planet. Change, 22(1-4), 49-58.

MS received 2 June 1999 and accepted in revised form 28 February 2001 